\title{
Ampulla of Vater Cancer Clinical Distant Metastasis TNM Finding v8
}

National Cancer Institute

\section{Source}

National Cancer Institute. Ampulla of Vater Cancer Clinical Distant Metastasis TNM

Finding v8. NCI Thesaurus. Code C134839.

A clinical finding about one or more characteristics of ampulla of Vater cancer, following the rules of the TNM AJCC v8 classification system as they pertain to distant metastases. 